\title{
Modulatory Effects of Antidepressant Classes on the Innate and Adaptive Immune System in Depression
}

\author{
Authors \\ H. A. Eyre ${ }^{1,2,3}$, H. Lavretsky ${ }^{2}$, J. Kartika ${ }^{1}$, A. Qassim', B. T. Baune ${ }^{1}$ \\ Affiliations \\ ${ }^{1}$ Discipline of Psychiatry, University of Adelaide, Adelaide, Australia \\ Semel Institute for Neuroscience and Human Behavior, UCLA, Los Angeles, USA \\ School of Medicine and Dentistry, James Cook University, Townsville, Australia
}

\author{
Key words \\ - antidepressant \\ - immune \\ - innate \\ - adaptive \\ inflammatory
}

\section{Abstract \\ $\nabla$}

Current reviews exploring for unique immunemodulatory profiles of antidepressant classes are limited by focusing mainly on cytokine modulation only and neglecting other aspects of the innate and adaptive immune system. These reviews also do not include recent comparative clinical trials, immune-genetic studies and therapeutics with unique neurotransmitter profiles (e.g., agomelatine). This systematic review extends the established literature by comprehensively reviewing the effects of antidepressants classes on both the innate and adaptive immune system. Antidepressants appear, in general, to reduce pro-inflammatory factor levels, particu- larly C-reactive protein (CRP), tumour necrosis factor (TNF)- $\alpha$, interleukin (IL)- $1 \beta$ and IL-6. We caution against conclusions as to which antidepressant possesses the greater anti-inflammatory effect, given the methodological heterogeneity among studies and the small number of comparative studies. The effects of antidepressant classes on adaptive immune factors are complex and poorly understood, and few studies have been conducted. Methodological heterogeneity is high among these studies (e.g., length of study, cohort characteristics, dosage used and immune marker analysis). We recommend larger, comparative studies - in clinical and pre-clinical populations. $\begin{array}{ll}\text { received } & 24.11 .2015 \\ \text { revised } & 01.01 .2016 \\ \text { accepted } & 28.01 .2016\end{array}$

Bibliography

Dol http://dx.doi.org/

10.1055/s-0042-103159

Published online:

March 7, 2016

Pharmacopsychiatry 2016;

49: 85-96

(c) Georg Thieme Verlag KG

Stuttgart · New York

ISSN 0176-3679

Correspondence

B. T. Baune, PhD, MD, MPH, FRANZCP

Professor and Chair of

Psychiatry

Discipline of Psychiatry

School of Medicine

University of Adelaide

Adelaide

SA 5005

Australia

Bernhard.Baune@Adelaide. edu.au

\section{Introduction \\ $\nabla$}

Novel treatment strategies for depression are urgently needed. Recent global data suggests unipolar depression currently ranks $11^{\text {th }}$ for disability-adjusted life years, a 37\% increase since 1990 [1]. The burden is expected to continue to grow into the $21^{\text {st }}$ century $[1,2]$. Hence, this is an unprecedented burden of depressive illness requiring increased effort to find novel therapeutic agents for treatment [3]. Additionally, more than $50 \%$ of patients on antidepressants will not achieve remission following initial treatment [4], and nearly one-third will not achieve remission even following several treatment steps $[5,6]$.

In the field of psychiatric immunology, much of the focus on the role of the immune system in depression has been placed on the innate immune response and inflammation [7]. The seminal meta-analysis [8] of 24 studies found significantly higher concentrations of the proinflammatory cytokines, tumour necrosis factor (TNF)- $\alpha$ and interleukin (IL)-6 in depressed subjects compared with control subjects. An updated meta-analysis [9] of IL-6, C-reactive protein (CRP) and TNF- $\alpha$ found higher levels of IL- 6 and CRP in depressed patients vs. controls (29 studies for IL-6 and 20 for CRP). These studies strengthen evidence that depression is accompanied by activation of the inflammatory response system [8]. Cytokines such as TNF- $\alpha$, IL-1 $\beta$, IL- 6 and interferon (IFN)- $\gamma$ have been repeatedly shown to exert effects on key processes such as neuroplasticity, neurotransmission, oxidative stress and neuroendocrinological functions that are considered to be central to the development of depression [10-14]. These pro-inflammatory cytokines are elevated in the brain and periphery, and are shown to facilitate negative pathophysiological consequences in both clinical and pre-clinical populations [10,11,15-17]. Pro-inflammatory cytokines have been found to impair hippocampal (HC) neuroplasticity (e.g., neurogenesis, synaptic plasticity, long-term potentiation (LTP)), induce glucocorticoid insensitivity of the hypothalamo-pituitary-adrenal (HPA) axis, increase oxidative stress in the $\mathrm{HC}$, reduce serotonin (5-HT) levels and create neurotoxic serotonergic 
metabolites (i.e., 3-hydroxykynurenine (3-HK) and quinolinic acid (QA) $[10,11,15-17]$. Astrocytes and microglia, also key components of the innate immune system, have also been found to play a role in the pathophysiology of depression [13]. Microglia, a major producer of pro-inflammatory cytokines and an important regulator of $\mathrm{HC}$ neuroplasticity, oxidative stress and QA, have been shown to be activated in depression [18]. Microglia are noted to produce detrimental processes, e.g., anti-neuroplastic, pro-oxidative, pro-inflammatory, when activated. They are noted to produce neuroprotective effects, e.g., antiinflammatory, pro-neuroplastic and anti-oxidative, when quiescent. A recent clinical study [18] provides an in vivo investigation of microglial activation, hence neuroinflammation, in depression. This study used positron emission tomography, specifically with the translocator protein density (TPSO) ligand which is shown to be increased in activated microglia. TPSO binding was compared between depressed and non-depressed subjects. Investigators found increased binding in all brain regions, especially the prefrontal cortex, anterior cingulate cortex and insula in depressed subjects. Moreover, astrocytes that have shown a prominent role in releasing neurotrophic and anti-oxidant factors have also been found to be activated in depression [19]. A range of clinical and pre-clinical studies suggest astrocytic abnormality in depression, leading to detrimental processes in the brain [20].

The most recent evidence from reviews and meta-analyses suggests that antidepressants may exert effects on the immune system. A meta-analysis of 22 studies by Hannestad et al. [21] explored the effect of antidepressants on serum pro-inflammatory cytokines, TNF $\alpha$, IL-1 $\beta$ and IL-6, in 603 depressed subjects. This is the latest study to quantitatively explore the immunemodulatory effects of antidepressants. A stratified subgroup analysis in this meta-analysis by class of antidepressants indicated that selective serotonin reuptake inhibitors (SSRI) may reduce levels of IL- 6 and TNF $\alpha$, whereas other types of antidepressants - while efficacious in antidepressant effects - did not appear to reduce cytokine levels, or showed trend evidence in a few studies only. Although these data suggest that SSRIs with their prominent 5-HT functions may be more anti-inflammatory than other agents, the available database of various classes of antidepressants affecting the immune system has not been critically evaluated yet. Beyond the abovementioned meta-analysis, it has been suggested that while noradrenalin reuptake inhibitor antidepressants suppress Th1-type cytokines (e.g., IFN- $\gamma$, IL-2 and TNF- $\alpha$ ) and shift the balance towards humoral immunity, SSRIs reduce the production of Th2-type cytokines (e.g., IL-4, IL-5, IL-6, IL-9, IL-10, and IL-13) and shift the balance toward cellular immune response $[22,23]$. These findings suggest the possibility of differential mechanistic effects of various antidepressant classes on immune function, which requires systematic evaluation.

An involvement of immune factors in the pathophysiology of depression is now considered to be far greater than that of only the innate immune system, inflammation and glia [19]. A complex interaction is suspected to occur in the central nervous system (CNS) between parts of the innate and adaptive immune system [24]. Systemic immune cells, namely macrophages and $T$ cells, have been found to have variously pro- and anti-neuroplastic, and pro- and anti-inflammatory effects on the brain $[13,19]$. These effects are dependent on cellular phenotype and environmental factors and systematic immune cells have been shown to variously influence neuroplasticity, cytokine production and oxidative stress (for reviews see $[13,19,25]$ ). Chemokines are involved in depression pathophysiology, likely through neuromodulatory effects, neurotransmitter-like effects, as well as regulation of neurogenesis and axon sprouting [26]. It is necessary to highlight that interactions between the innate and adaptive immune systems in the brain are numerous and complex. These interactions require further investigation and can be explored further in these reviews [25,27]. A systematic and critical review exploring the effects of antidepressant classes on both innate and adaptive immune factors has not been conducted to date, and such a review is timely given the broad involvement of the immune system in depression as well as the increasing evidence of class-specific effects of antidepressants on immune function. Our comprehensive review also includes recent comparative and novel (e.g., melatonin-active) antidepressant studies in this area.

Taken together, this systematic review extends from the established literature by comprehensively reviewing the effects of various antidepressants classes on both innate and adaptive immune factors also including recent comparative studies, immune-genetic studies and antidepressants with unique neurotransmitter mechanisms.

\section{Methods \\ $\nabla$}

The literature search for this review was carried out by J.K. and A.Q. using the PRISMA (Preferred Reporting Items for Systematic Review and Meta-Analyses) guidelines as they apply to systematic reviews [28]. Databases including PubMed, Scopus, Google Scholar, ScienceDirect and PsycInfo were used. The following search terms were applied: ((((antidepressants OR antidepress* OR selective serotonin reuptake inhibitor OR SSRI OR serotonin noradrenaline reuptake inhibitor OR SNRI OR tricyclic antidepressant OR TCA OR melatonin antidepressant OR noradrenaline reuptake inhibitor OR NaSSA OR noradrenergic and specific serotonergic antidepressants $\mathrm{OR}$ serotonin OR noradrenaline OR agomelatine)) AND (innate OR adaptive OR cytokine OR inflammation OR inflammatory OR chemokine OR microglia OR astrocyte OR monocyte OR T cell OR macrophage OR miRNA OR glial OR immune)) AND (depressive symptoms OR depress* OR major depressive disorder)). We included papers published between 1980 to May 2014, and in the English language. For clinical studies in human populations, the antidepressants must be approved by the Food and Drug Administration (FDA) for the treatment of Major Depressive Disorder (MDD) and the studies must have a DSM diagnosis of MDD. Exclusion criteria applied to patients with other primary or concurrent psychiatric or neurological conditions (e.g., dementia, Parkinson's disease, schizophrenia). Pre-clinical pharmacological studies were excluded. We only included studies which individually or comparatively explored the immune-modulatory effects of individual antidepressant classes (at least 2 classes). A search of the databases returned 3165 abstracts. 198 full text manuscripts were retrieved. The rest of the abstracts were excluded due to the above exclusion criteria with 121 articles remaining for this review. See $\bullet$ Fig. 1 for graphical representation. 


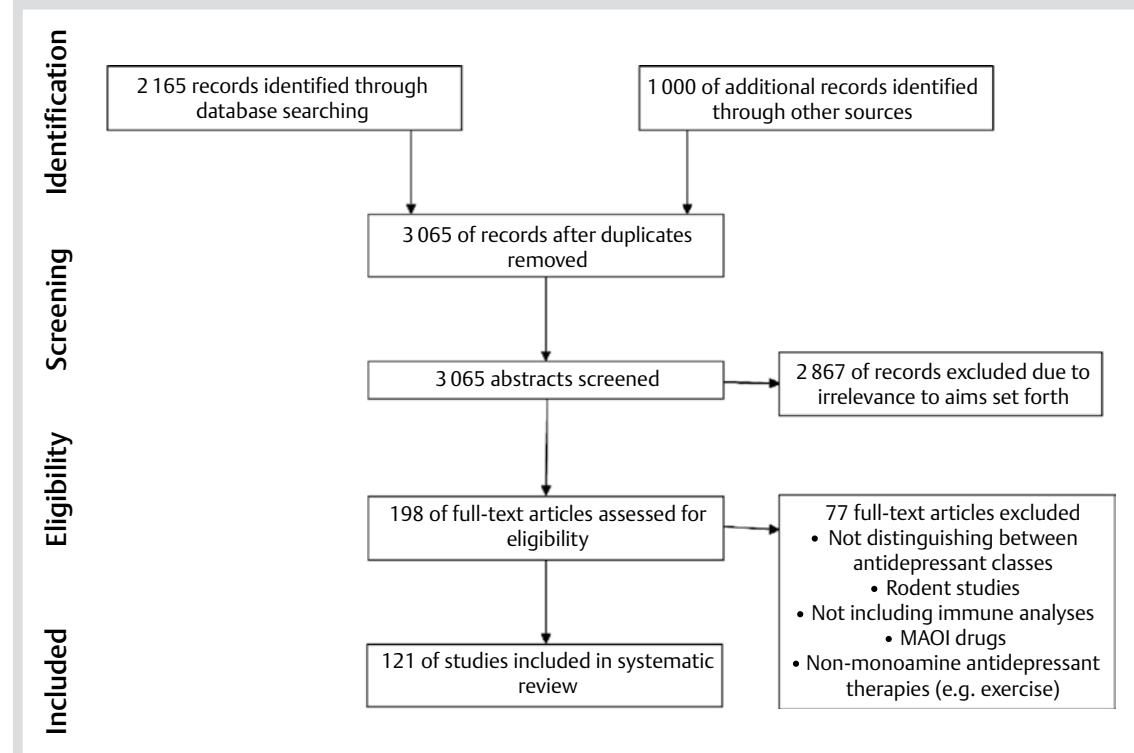

Fig. 1 Flow diagram for study inclusion and exclusion.

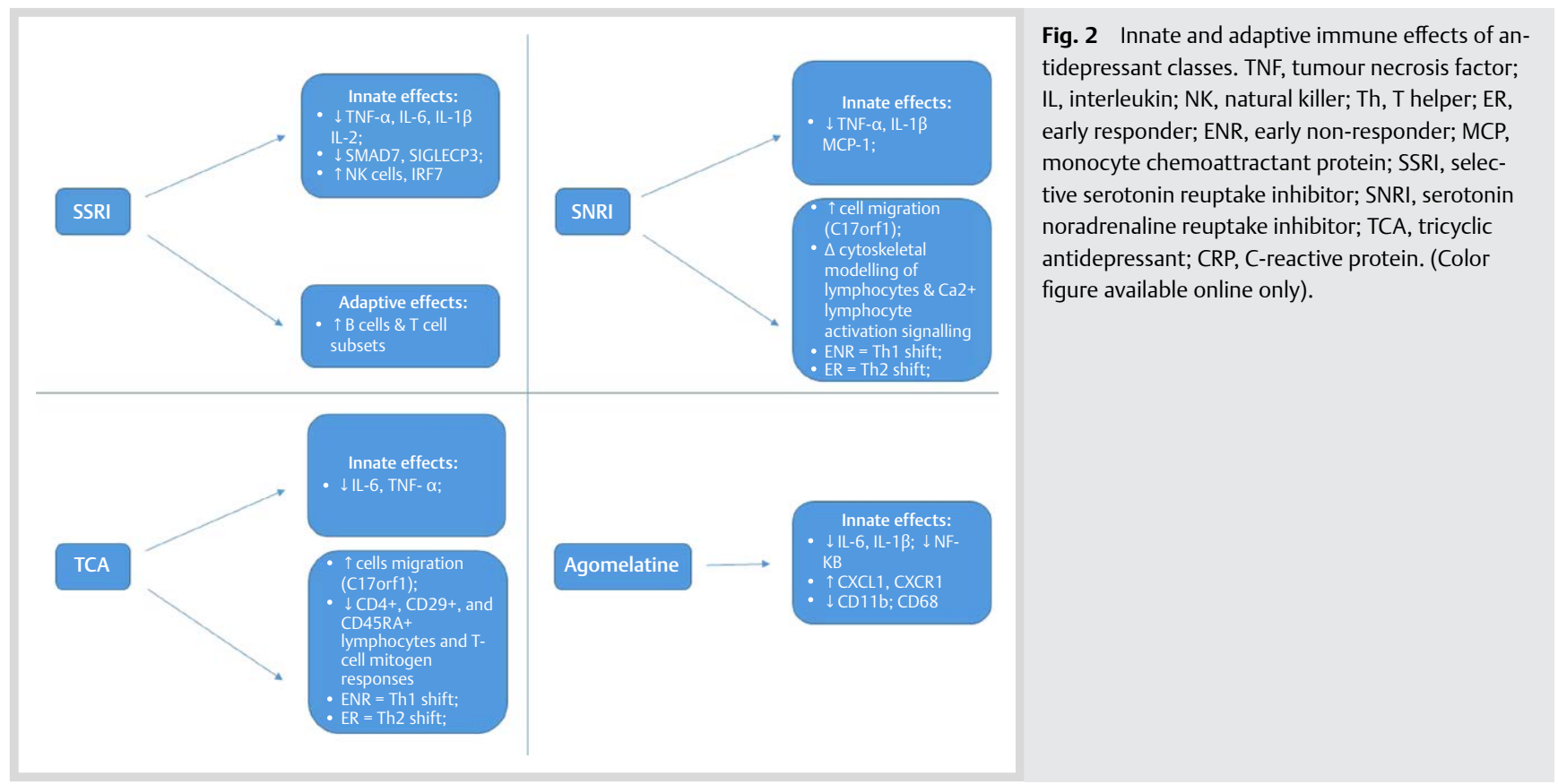

\section{Assessing the Effects of Antidepressant Classes on the Immune System \\ $\nabla$}

The following section will explore the immune-modulatory effects of antidepressants with a focus on the classes of antidepressants in clinical studies. We will outline the effects of various classes initially, then focus on comparative studies in this area. We explore effects on both innate and adaptive immune factors; we have chosen to explore these 2 areas separately, however there is overlap within studies between the two. We will not be reviewing studies which fail to distinguish immune effects between antidepressant classes since reviews on literature without distinction of antidepressant classes have been undertaken and published elsewhere $[23,29]$. See $\bullet$ Fig. 2 for an overview of the immune effects of antidepressant classes.
The effect of selective serotonin reuptake inhibitors on the immune system

Effects of SSRIs on innate immune factors

A larger number of studies explored innate immune effects of SSRIs [30-40].

\section{Meta-analyses and systematic reviews}

When considering the effects of SSRIs on cytokines, we must initially review the most rigorous study to date on this issue, which is the quantitative meta-analysis by Hannestad et al. [21]. As mentioned above, this study explored the effects of antidepressants on TNF- $\alpha$, IL- 6 and IL- $1 \beta$ in subjects with a diagnosis of MDD who were otherwise healthy adults. This study made a number of key findings. With TNF- $\alpha$, subgroup analysis was only possible for SSRIs; for IL-6 sub -analysis was possible between SSRIs and TCAs; for IL- $1 \beta$, sub-analysis was not possible as $5 / 6$ studies used SSRIs. For TNF- $\alpha$, random-effects modelling showed 
no effect for SSRIs $(\mathrm{p}=0.16)$; however with fixed-effects (less stringent than random-effects) modelling there was a trend shown ( $\mathrm{p}=0.06 ; \mathrm{n}=199)$. There was substantial methodological heterogeneity noted between SSRI studies. For IL-6, randomeffects modelling showed an effect for SSRIs $(p=0.02)(n=79)$; TCAs did not affect IL-6 ( $p=0.2 ; n=24)$. These studies were from a relatively small subsample, with significant heterogeneity and therefore must be considered with that limitation in mind.

Primary research not considered in previous metaanalyses

Studies which were not included in the Hannestad et al. metaanalysis and which provide useful information include Mamdani et al. 2011 [39] and 2014 [40]. The first study by Mamdani et al. [39] investigated the peripheral gene expression patterns of response to citalopram treatment for MDD. An 8-week trial was run with 63 subjects; citalopram administered (10-60 mg/day); peripheral blood mononuclear cells assessed along with postmortem brain samples from a subset of subjects ( $n=15)$ (vs. 11 sudden-death controls). A total of 32 probesets were differentially expressed according to citalopram response. Response to treatment was associated with upregulated Interferon regulator factor 7 (IRF7) response peripherally; decreased IRF7 was also found in the prefrontal cortex of MDD subjects with no toxicological evidence of antidepressant use at time of death. IRF7 has been shown to complex with IRF1, IRF3 and histone transacetylases to control transcription of the pro-inflammatory cytokine, interferon- $\alpha[41,42]$. The authors speculate IRF7 upregulation could be the result of citalopram stimulating fluctuations in interferon levels [41], or through IRF7 promoter methylation [43].

An extension of the above Mamdani et al. [40] study investigated pre-treatment peripheral gene expression differences between future remitters and non-responders to citalopram treatment (10-60 mg/day). In the same study design as previously, with 77 subjects, 434 probesets displayed significant correlation to change in score and 33 probesets were differentially expressed between eventual remitters and non-responders. Probesets for SMAD 7 (SMA- and MAD-related protein 7) and SIGLECP3 (sialic acid-binding immunoglobulin-like lectin, pseudogene 3) were the most significant differentially expressed genes and downregulated in individuals who responded to treatment. SMAD7 is responsible for the recruitment of ubiquitinases to induce the degradation of transforming growth factor- $\beta$ (TGF $\beta$ ) receptor and thus negatively regulates the TGF $\beta$ signalling pathway [44]. TGF $\beta$ is considered to be a Th3-type cytokine and plays a major role in guarding a balance between Th1 and Th2 cytokines (or pro and anti-inflammatory) [45]. Therefore, the authors hypothesise remitters appear to have an advantage in that TGF $\beta$ levels are likely to be at a higher, and possibly advantageous, level resulting in a more rapid increase of TGF $\beta$ following treatment. SIGLECs (sialic acid-binding immunoglobulin-like lectins) are lectins involved in interactions between individual cells and take part in cellular regulation within the immune system, however their role in psychiatric disorders is poorly understood. Recently, Siglec-9 [46], Siglec-10 [47] and Siglec-11 [48] have been shown to dampen response of innate immunity through binding to other sialylated compounds. They may also have a role in microglial and neurite modulation. Clearly the immune effects of these compounds require further exploration.

\section{Effects of SSRIs on adaptive immune factors}

Several studies explore the effects of SSRIs on adaptive immune cells [35,49-51]. Early studies in this area explored the effect of SSRIs for 4-12 weeks in MDD patients and noted a main finding - SSRIs decrease the number of circulating NK cells without affecting other lymphocyte subsets [52-55]. Increased counts of NK cells might occur due to stimulation of their serotonergic receptors as the result of increased levels of 5-HT caused by long-term SSRI treatment [51]. A more recent paper by Hernandez et al. [51] explored the effect of a 52-week treatment with SSRIs (various types) on lymphocyte subsets. This study included 31 adult MDD subjects and 22 healthy controls. The patients showed remission of depressive episodes after 20 weeks of treatment along with an increase in NK cell and B cell populations, which remained increased until the end of the study. At the 52nd week of treatment, patients showed an increase in the counts of NK cells ( $396 \pm 101$ cells $/ \mathrm{mL}$ ) and B cells (268 \pm 64 cells/ $\mathrm{mL}$ ) compared to healthy volunteers $(\mathrm{NK}, 159 \pm 30$ cells $/ \mathrm{mL} ; \mathrm{B}$ cells, $179 \pm 37$ cells $/ \mathrm{mL}$ ). Activated mature B lymphocytes proliferate in a time-dose-dependent manner with regards to either 5 -HT concentration or $5-\mathrm{HT}_{1 \mathrm{~A}}$ receptor agonist concentration [56]. Therefore, the authors suggest that increased extracellular levels of 5-HT caused by long-term SSRI treatment may have stimulated the proliferation of B lymphocytes in patients with MDD. The increase in T cell subsets at W36 might result from the proliferative effect of IL-2, whose serum levels increase at W20 during SSRI treatment [36].

\section{Summary of the immune effects of SSRIs}

The immune effects of SSRIs are the most researched to date. It appears SSRIs have an anti-inflammatory effect in general. SSRIs are shown to upregulate IRF7 gene activity, a transcription regulator of the IFN- $\alpha$. SSRIs also appear to stimulate the proliferation of B lymphocytes in patients with MDD.

\section{The effect of serotonin and noradrenaline reuptake inhibitors on the immune system}

Overall, a relatively limited number of studies explored the effect of SNRI antidepressants on innate and adaptive immune factors. The primary studies exploring the innate immune effects of SNRIs explore the effects of SNRIs on innate immune factors and aim to explore immune profiles associated with response vs. non-response. There is one study exploring the leukocyte gene expression profile changes from SNRIs. To date there is no meta-analytical or systematic review data on the immune effects of SNRIs.

\section{SNRIs affecting innate immune factors}

When evaluating the above-mentioned Hannestad et al. metaanalysis [21], it was not possible to explore the effects of SNRIs as a subgroup analysis as there were too few studies. As mentioned previously, it has been suggested that while noradrenalin reuptake inhibitor antidepressants suppress Th1-type cytokines (e.g., IFN- $\gamma$, IL-2 and TNF- $\alpha$ ) and shift the balance towards humoral immunity [22,23].

One of these earlier studies by Piletz et al. [57] explored the effect of venlafaxine treatment $(150-225 \mathrm{mg} /$ day $)$ on immune biomarkers in MDD patients (i.e. TNF- $\alpha$, IL-1 $\beta$, MCP-1, CRP, CD40L). Initially this study enrolled 14 MDD patients and 17 controls; at baseline they found subjects with MDD had significantly higher baseline levels of TNF- $\alpha(P=0.04)$, IL-1 $\beta(P=0.03)$, and MCP-1 ( $\mathrm{P}=0.02)$ compared to controls. A subset of the MDD 
patients consented to undergo treatment with venlafaxine (at lower doses an SSRI; at higher doses also an NRI) for 8 weeks. By week 8 , all treatment completers had responded therapeutically. However, levels of TNF- $\alpha$, IL-1 $\beta$, and MCP- 1 remained elevated. A concave quadratic equation described the associations between plasma venlafaxine concentrations and IL-1 $\beta$ ( $P=0.03)$, TNF- $\alpha$ $(\mathrm{P}=0.09)$, and MCP-1 $(\mathrm{P}=0.02)$, Therefore, these biomarkers may have become selectively lowered in the serotonergic dose range of venlafaxine. Interestingly, the authors discussed the correlation of MCP-1 with cardiovascular pathology. We agree with this suggestion, however as outlined above, MCP-1 as a chemokine may also effect neurobiological processes directly and therefore this requires further investigation.

A recent prospective cohort study by Li et al. [58] explored the effect of an 8-week trial of venlafaxine monotherapy (75$225 \mathrm{mg} /$ day) on plasma TNF- $\alpha$ levels in adult patients with MDD. This study included 64 depressed subjects. Levels of TNF- $\alpha$ significantly decreased after 8 weeks of venlafaxine treatment in both responders and non-responders $(p<0.001$ and $p=0.03$, respectively). Even more interestingly, compared to nonresponders, the responder group had a greater reduction in TNF- $\alpha(p=0.01)$. This suggests the extent of TNF- $\alpha$ reduction by venlafaxine may be associated with the efficacy of venlafaxine. Another study by Fornaro et al. [59] explored the cytokine-modulatory effects of duloxetine among a small sample size of 30 MDD patients and 32 healthy controls. This study used an innovative approach to explore immune-modulation between early responders and early non-responders; a wide range of inflammatory markers were tested across a 12-week treatment trial of duloxetine ( $60 \mathrm{mg} /$ day). Early responders (ER: defined at week 6 by reduction $>50 \%$ of baseline Hamilton Depression score) and early non-responders (ENR) showed opposite trends in cytokine levels during duloxetine treatment: ENRs were characterized by baseline Th2 shift compared to controls (lower IL-1 $\beta$, IFN- $\gamma$ and TNF- $\alpha$ ) with increase in Th1 cytokines levels during treatment (increase of IL-1 $\beta$, IL-12, IFN- $\gamma$, IL-1 $\beta / \mathrm{IL}-10$ and TNF- $\alpha / \mathrm{IL}-10$, decrease of IL-10), achieving clinical response at week 12; ER were characterized by baseline Th2-to-Th1 relative switch compared to ENRs (higher IL-1 $\beta$, IL-1 $\beta /$ IL-10 and TNF- $\alpha /$ IL-10) with reduction in Th1 cytokines levels during treatment (decrease of TNF- $\alpha$ and TNF- $\alpha /$ IL-10), achieving clinical response at week 6 . This may suggest duloxetine treatment could divide depressed patients into at least 2 subgroups per clinical and laboratory characteristics.

\section{SNRIs affecting adaptive factors}

Very few studies have explored the effects of SNRIs on cellular immune markers $[57,60]$. One notable study by Kalman et al. [60] explored the gene expression profile of venlafaxine $(75 \mathrm{mg} /$ day) on 6 depressed elderly subjects over 4 weeks. In this study of lymphocyte expression, 31 genes were more highly expressed and 26 transcripts were found to be significantly less abundant. These genes were implicated in ionic homeostasis were differentially expressed, as were genes associated with cell survival, neural plasticity, signal transduction, and metabolism. Specific to the immune system, genes responsible for cell migration (e.g., C17orf1) were over-expressed; and gene interference was noted with cytoskeletal remodeling of lymphocytes and Ca2+-signalling required for activation of lymphocytes (e.g., P2RX1). This suggests there are effects of SNRIs on cellular immune functions, however how these functions are associated with depression pathophysiology requires further exploration. Clearly, follow-up studies are required which look at these immune effects in larger cohorts and in varying age ranges.

\section{Summary of the immune effects of SNRIs}

Immune effects of SNRIs have not been extensively studied to date, and hence require further investigation. They do appear to have anti-inflammatory effects, however this may depend on their dose range. The immune effects may differ depending on if patients are early responders or early non-responders. When SNRI effects on lymphocyte gene expression were measured, they were found to affect genes responsible for cell migration, lymphocyte cytoskeletal remodeling and lymphocyte activation.

\section{The effect of tricyclic antidepressants on the immune system}

There is little data available on the innate and adaptive immune effects of TCAs. We are aware of 3 studies specifically exploring innate immune effects and 2 studies exploring adaptive immune effects. These studies are reviewed in more detail.

\section{Tricyclic antidepressants affect innate immune factors}

A number of earlier studies explored immune-modulatory effects of TCAs [61,62]. The Hannestad et al. [21] meta-analysis conducted a subgroup analysis on the effects of TCAs on IL-6. Using the random-effects model, there was no effect of TCA treatment $(n=24)$ on IL-6 levels (SMD $=-0.51$ (95\% CI: -1.28 , $0.26), Z=1.3, p=0.2$ ). Subgroup analyses were not possible for TNF- $\alpha$ and IL-1 $\beta$ due to insufficient study numbers.

Recently, a study by Uher et al. [22] has begun to readdress this area in a comparative study (outlined in the section below). A study by Lanquillon et al. [61] conducted a controlled study to assess the effects of 6 weeks of treatment with amitriptyline on a range of inflammatory markers (i.e., white cell count, IL-6, TNF- $\alpha$ and CRP) in MDD subjects. In this study there were 24 MDD subjects and 15 healthy controls; amitriptyline doses ranged between $25-250 \mathrm{mg} /$ day. In comparison to the controls, unstimulated pretreatment PBMC production of IL-6 was significantly decreased in the responders; whereas it was significantly increased in the non-responder subgroup. Post-treatment values did not differ significantly among the patient and control groups. Pre-treatment levels of TNF- $\alpha$ were increased in both patient subgroups, with a significant decrease during treatment only in the responder subgroup. Pretreatment levels of IL-6/10 mononuclear cells and the ratio between lymphocytes and monocytes acted as independent variables with regard to the clinical response. This suggests TNF- $\alpha$ is related to clinical response; IL-6 levels might dichotomise the patients into subsequent responders and nonresponders.

Tricyclic antidepressants affect adaptive immune factors We are aware of only 2 studies exploring the adaptive effects of TCAs in depression $[61,63]$. The first one is the abovementioned study by Lanquillon et al. [61]. Another study by Schleife et al. [63] investigated dynamic lymphocyte characteristics before and after 6 weeks of nortriptyline monotherapy treatment (wide dose range with serum at 6 weeks $86.4 \pm 57.2 \mathrm{ng} / \mathrm{ml}$ ). In this study of 21 medically healthy young adults with MDD, evidence of increased lymphocyte activation to mitogen challenge and decreased natural killer (NK) cell numbers and function were noted during acute depression. 15 subjects were followed longitudinally. T, CD4+, CD29+, and CD45RA + lymphocytes and $\mathrm{T}$-cell mitogen responses decreased significantly $(\mathrm{P}<0.05)$ dur- 
ing 6 weeks of pharmacotherapy and concurrent clinical improvement. There was no change in NK activity or CD56+ cells. The longitudinal effects appeared related to clinical improvement but unrelated to serum tricyclic antidepressant levels.

\section{Summary of the immune effects of tricyclic antidepressants}

TCAs appear to have anti-inflammatory effects. Indeed, TNF- $\alpha$ may provide a biomarker for treatment response; IL-6 may assist in predicting responders vs. non-responders. These findings remain to be reproduced. With regards to the cellular immune effects of TCAs, treatment with TCAs was associated with decreased T, CD4+, CD29+, and CD45RA+ lymphocytes and T-cell mitogen responses.

\section{Studies directly comparing the immune-modulatory effects of antidepressant classes}

Comparative studies directly comparing the immune-modulatory effects of antidepressant classes are a preferred method of assessing unique modulatory profiles in this area. If 2 or more antidepressant classes are compared in the same study methodology, it enhances the quality of the analysis. Without a comparative analysis - as can be seen in the above sections exploring the effect of individual antidepressant classes separately - a substantial amount of methodological heterogeneity is observed (e.g., antidepressant dose, immune markers tested, cohort char- acteristics and duration) that makes comparisons difficult. In the sections below we outline studies comparing both the innate and adaptive immune-modulatory profiles of antidepressant classes in MDD subjects.

\section{Comparative studies: exploring innate immune factors}

We are aware of 5 studies which compare the humoral immune modulatory effects of antidepressants [22,64-67] ( $\bullet$ Table 1). Some studies find no difference between antidepressant classes and others find a significant difference. A recent multicentre, open-label, randomized clinical trial by Uher et al. [22] aimed to determine if CRP predicted differential response to escitalopram (SSRI) and nortriptyline. These drugs were administered between $5-30 \mathrm{mg} /$ day and $50-200 \mathrm{mg} /$ day, respectively. This study involved 241 adult subjects with MDD and followed them for 12 weeks. The study found the CRP level at baseline differentially predicted treatment outcome with the 2 antidepressants. In cases with low levels of CRP $(<1 \mathrm{mg} / \mathrm{L})$ at baseline, the improvement on the MADRS score after 12 weeks of treatment was 3 points greater in patients treated with escitalopram compared to nortriptyline. On the contrary, in patients showing high CRP levels at baseline, an improvement on the MADRS score was 3 points higher in nortriptyline- compared to escitalopramtreated patients. Unfortunately, there was no follow-up measurement of CRP.

Another study by Cattano et al. [65] employing the same study design as above also compared the immune effects between

Table 1 Clinical studies comparing the innate immune effects of antidepressants.

\begin{tabular}{|c|c|c|c|c|c|c|}
\hline Ref. & Objective & $\begin{array}{l}\text { Study type/details } \\
\text { Participant details }\end{array}$ & $\begin{array}{l}\text { Depression } \\
\text { details }\end{array}$ & $\begin{array}{l}\text { Antidepres- } \\
\text { sant info }\end{array}$ & $\begin{array}{l}\text { Immune } \\
\text { markers }\end{array}$ & Results \\
\hline $\begin{array}{l}\text { Narita, K } \\
\text { et al. } 2006 \\
{[60]}\end{array}$ & $\begin{array}{l}\text { Cross-section- } \\
\text { al comparison } \\
\text { of plasma } \\
\text { TNF- } \alpha \text { and adi- } \\
\text { ponectin levels } \\
\text { in remitted } \\
\text { MDD patients } \\
\text { on long-term } \\
\text { maintenance } \\
\text { therapy and } \\
\text { control }\end{array}$ & $\begin{array}{l}\text { Study type: cross-sectional } \\
\text { Participant details: } \\
21 \text { patients: } 10 \mathrm{M}, 11 \mathrm{~F} \\
\text { age: } 60.9 \pm 7.1 \text { yrs } \\
\text { No major illness; no history of } \\
\text { any illness over } 4 \text { wks. } \\
\text { No meds except benzodiaz- } \\
\text { epine } \\
20 \text { healthy volunteers } \\
\text { Follow-up duration: n/a } \\
\text { Rx: monotherapy (various) } \\
\text { fluvoxamine (2), paroxetine } \\
\text { (9), milnacipran (10) }\end{array}$ & $\begin{array}{l}\text { Diagnosis: MDD } \\
\text { (DSM-IV) } \\
\text { Measured by: } \\
\text { HAM-D-17 } \\
\text { (remission: } \leq 7 \text { ) } \\
\text { Type of de- } \\
\text { pression: On } \\
\text { remission, on } \\
\text { treatment }>6 \mathrm{~m}\end{array}$ & $\begin{array}{l}\text { Medication: } \\
\text { fluvoxamine } \\
\text { (SSRI), parox- } \\
\text { etine (SSRI), } \\
\text { milnacipran } \\
\text { (SNRI), no } \\
\text { dose specified, } \\
\text { results not } \\
\text { categorised } \\
\text { Duration: at } \\
\text { least } 6 \text { months } \\
\text { (18.7 } \pm 8.9 \text { ) }\end{array}$ & $\begin{array}{l}\text { Type: } \\
\text { venous } \\
\text { At: } \\
\text { 8-9am } \\
\text { fasting } \\
\text { Measure: } \\
\text { plasma } \\
\text { TNF- } \alpha \\
\text { (CLIA), } \\
\text { and adi- } \\
\text { ponectin } \\
\text { (ELISA) }\end{array}$ & $\begin{array}{l}\text { Clinical results } \\
\mathrm{n} / \mathrm{a} \text { (already remitted) } \\
\text { Immune results } \\
\text { - TNF- } \alpha \text { is significantly lower in } \\
\text { remitted group ( } p<0.001) \\
\text { - adiponectin is significantly } \\
\text { higher in remitted group } \\
\text { ( } p=0.036) \\
\text { - TNF- } \alpha \text { and adiponectin not dif- } \\
\text { ferent between SSRIs vs. SNRIs }\end{array}$ \\
\hline $\begin{array}{l}\text { Uher et al. } \\
2014 \text { [19] }\end{array}$ & $\begin{array}{l}\text { To determine } \\
\text { if C-reactive } \\
\text { protein (CRP) } \\
\text { predicts } \\
\text { differential } \\
\text { response to } \\
\text { escitalopram } \\
\text { (SSRI) and } \\
\text { nortriptyline } \\
\text { (NRI/TCA). }\end{array}$ & $\begin{array}{l}\text { Study type: multicentre, } \\
\text { open-label, randomized clini- } \\
\text { cal trial } \\
\text { Participant details: } \\
241 \text { adults both men and } \\
\text { women with MDD } \\
\text { age: escitalopram } \\
(40.1 \pm 11.6) \text {; nortriptyline } \\
(41.2 \pm 11.4) \\
\text { Included patients with co- } \\
\text { morbid disorders, severe } \\
\text { illness, suicidal ideation. } \\
\text { No mania, hypomania. } \\
20 \text { healthy volunteers } \\
\text { Follow-up duration: } 12 \\
\text { weeks } \\
\text { Rx: escitalopram ( } \mathrm{N}=115 \text { ) or } \\
\text { nortriptyline ( } \mathrm{N}=126)\end{array}$ & $\begin{array}{l}\text { Diagnosis: MDD } \\
\text { - DSM-IV } \\
\text { Measured by: } \\
\text { MADRS; HAM-D; } \\
\text { BDI } \\
\text { Type of depres- } \\
\text { sion: unipolar. }\end{array}$ & $\begin{array}{l}\text { Medication: } \\
\text { Escitalopram - } \\
\text { initially } 10 \mathrm{mg} / \\
\text { day, range } \\
5-30 \mathrm{mg} / \text { day. } \\
\text { Nortriptyline } \\
\text { initial } 50 \mathrm{mg} / \\
\text { day, range } \\
50-200 \mathrm{mg} / \\
\text { day } \\
\text { Duration: } 12 \\
\text { wks }\end{array}$ & $\begin{array}{l}\text { Type: } \\
\text { venous } \\
\text { At: no } \\
\text { time } \\
\text { given } \\
\text { Measure: } \\
\text { hsCRP } \\
\text { serum. }\end{array}$ & $\begin{array}{l}\text { CRP level at baseline differential- } \\
\text { ly predicted treatment outcome } \\
\text { with the } 2 \text { antidepressants. } \\
\text { Low levels of CRP ( }<1 \mathrm{mg} / \mathrm{L}) \text { : } \\
\text { improvement on the MADRS } \\
\text { score was } 3 \text { points higher with } \\
\text { escitalopram than with nortrip- } \\
\text { tyline. High CRP levels: improve- } \\
\text { ment on the MADRS score was } 3 \\
\text { points higher with nortriptyline } \\
\text { than with escitalopram. } \\
\text { CRP and its interaction with } \\
\text { medication explained more than } \\
10 \% \text { of individual-level variance } \\
\text { in treatment outcome. }\end{array}$ \\
\hline
\end{tabular}


Table 1 Continued.

\begin{tabular}{|c|c|c|c|c|c|c|}
\hline Ref. & Objective & $\begin{array}{l}\text { Study type/details } \\
\text { Participant details }\end{array}$ & $\begin{array}{l}\text { Depression } \\
\text { details }\end{array}$ & $\begin{array}{l}\text { Antidepres- } \\
\text { sant info }\end{array}$ & $\begin{array}{l}\text { Immune } \\
\text { markers }\end{array}$ & Results \\
\hline $\begin{array}{l}\text { Cattaneo } \\
\text { et al. } 2013 \\
{[61]}\end{array}$ & $\begin{array}{l}\text { To assess the } \\
\text { leukocyte } \\
\text { mRNA expres- } \\
\text { sion of genes } \\
\text { relating to } \\
\text { glucocorticoid } \\
\text { reception } \\
\text { function, } \\
\text { inflammation } \\
\text { and neuro- } \\
\text { plasticity in } \\
\text { healthy and } \\
\text { depressed } \\
\text { subjects } \\
\text { treated with } \\
\text { escitalopram } \\
\text { or nortriptyl- } \\
\text { ine. }\end{array}$ & $\begin{array}{l}\text { Study type: multicentre, open- } \\
\text { label, randomized clinical trial } \\
\text { Participant details: } 74 \text { patients } \\
(31 \mathrm{M}, 43 \mathrm{~F}), \geq 2 \text { wks drug- } \\
\text { free before trial. } \\
\text { Age } 38.3 \pm 10.9 \\
\text { Duration: } 8 \text { wks } \\
\text { Monotherapy: either escitalo- } \\
\text { pram ( } n=38 \text { ) or nortriptyline } \\
(n=36) \\
\text { Controls } n=34(19 \mathrm{M}, 15 \mathrm{~F}) \text {. } \\
\text { Age } 35.2 \pm 8\end{array}$ & $\begin{array}{l}\text { Diagnosis MDD } \\
\text { DSM-IV/ICD-10 } \\
\text { Measured sever- } \\
\text { ity by: HRSD-17, } \\
\text { MADRS, BDI. } \\
\text { Mean score } \\
\text { baseline } \\
\text { HRSD-17; } \\
21.8 \pm 5.3 \\
\text { MADRS } \\
28.7 \pm 6.7 \\
\text { BDI } 28.2 \pm 9.7 \\
\text { Response } \\
\text { defined as }>50 \% \\
\text { reduction in } \\
\text { MADRS from } \\
\text { baseline to } \\
12 \text { wks }\end{array}$ & $\begin{array}{l}\text { Medication: } \\
\text { Escitalopram - } \\
\text { initially } 10 \mathrm{mg} / \\
\text { day, range } \\
5-30 \mathrm{mg} / \text { day. } \\
\text { Nortriptyline } \\
\text { initial } 50 \mathrm{mg} / \\
\text { day, range } \\
50-200 \mathrm{mg} / \\
\text { day }\end{array}$ & $\begin{array}{l}\text { Venous } \\
\text { blood } \\
\text { leukocyte } \\
\text { mRNA } \\
\text { expres- } \\
\text { sion of } \\
\text { IL-1a, } \\
\text { IL-1B, } \\
\text { IL-4, IL-6, } \\
\text { IL-7, IL-8, } \\
\text { IL-10, } \\
\text { TNF-a, } \\
\text { MIF }\end{array}$ & 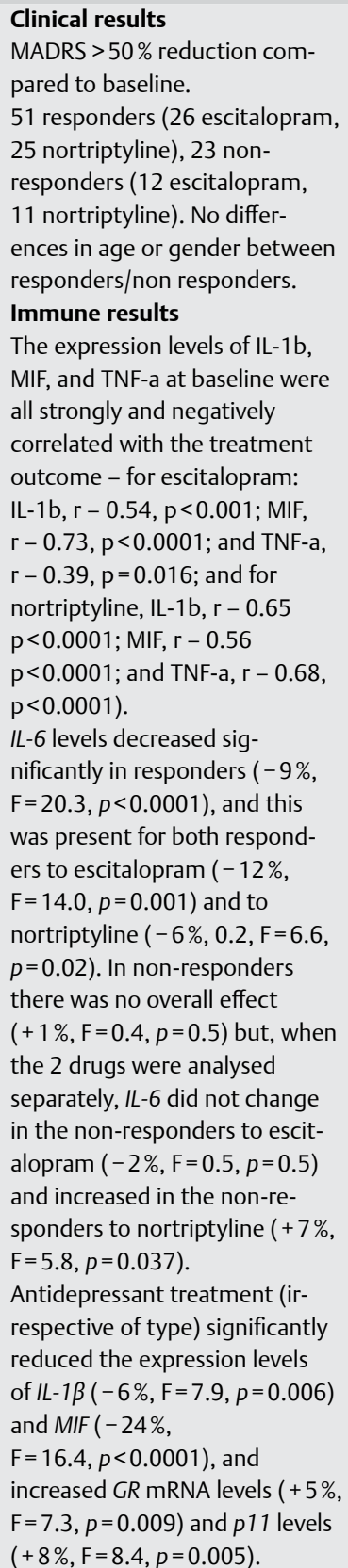 \\
\hline $\begin{array}{l}\text { Change et } \\
\text { al. } 2012 \\
{[62]}\end{array}$ & $\begin{array}{l}\text { Effect of ven- } \\
\text { lafaxine and } \\
\text { fluoxetine on } \\
\text { CRP levels in } \\
\text { patients with } \\
\text { MDD }\end{array}$ & $\begin{array}{l}\text { Study type: cohort } \\
\text { Participant details: } 149 \text { ( } 42 \mathrm{M} \text {, } \\
107 \mathrm{~F} \text { ) consecutive patients } \\
\text { with MDD from National } \\
\text { Cheng Kung University Hospi- } \\
\text { tal selected. } 112 \text { chosen after } \\
\text { fulfilling criteria. } \\
\text { Age } 38.8 \pm 12.4 \\
\text { Duration: } 6 \text { wks } \\
\text { Monotherapy: Randomly as- } \\
\text { signed to either fluoxetine or } \\
\text { venlafaxine } \\
\text { Controls: nil }\end{array}$ & $\begin{array}{l}\text { Diagnosis MDD } \\
\text { DSM-IV } \\
\text { Measured sever- } \\
\text { ity by } 21 \text {-item } \\
\text { HRSD } \\
\text { Mean score } \\
\text { baseline: } \\
\text { HRSD } 23.9 \pm 6.2 \\
\text { Response } \\
\text { defined as }>50 \% \\
\text { reduction in } \\
\text { HRSD }\end{array}$ & $\begin{array}{l}\text { Medication } \\
\text { Fluoxetine: } \\
\text { initial } 20 \mathrm{mg} \text {, } \\
\text { titrated to } \\
80 \mathrm{mg} \text { by } \\
20 \mathrm{mg} \text { each } \\
\text { time. } \\
\text { Venlafaxine: } \\
\text { Initial } 37.5 \mathrm{mg} \text {, } \\
\text { titrated to } \\
75 \mathrm{mg} . \\
\text { Lorazepam } \\
\text { allowed con- } \\
\text { comitantly, } \\
\text { to a maximal } \\
\text { dose of } 6 \mathrm{mg} \\
\text { daily. }\end{array}$ & $\begin{array}{l}\text { Fasting } \\
\text { venous } \\
\text { blood. } \\
\text { Taken } \\
\text { before } \\
\text { study and } \\
\text { after } 6 \\
\text { wks. } \\
\text { CRP. }\end{array}$ & $\begin{array}{l}\text { Immune } \\
\text { Baseline CRP (all) } 315 \pm 176.8 \\
\text { After } 6 \text { wks } 769.414 \pm 144.7 \\
\text { ( } p<0.001) \text {. Both fluoxetine } \\
\text { and venlafaxine groups had } \\
\text { increased CRP after } 6 \text { wks. } \\
\text { Patient with higher CRP at } \\
\text { baseline had poorer treatment } \\
\text { response. } \\
\text { Association between base- } \\
\text { line CRP and HAM-D was not } \\
\text { significant }\end{array}$ \\
\hline
\end{tabular}


Table 1 Continued.

\begin{tabular}{|c|c|c|c|c|c|c|}
\hline Ref. & Objective & $\begin{array}{l}\text { Study type/details } \\
\text { Participant details }\end{array}$ & $\begin{array}{l}\text { Depression } \\
\text { details }\end{array}$ & $\begin{array}{l}\text { Antidepres- } \\
\text { sant info }\end{array}$ & $\begin{array}{l}\text { Immune } \\
\text { markers }\end{array}$ & Results \\
\hline $\begin{array}{l}\text { Yoshimura } \\
\text { et al. } 2009 \\
{[63]}\end{array}$ & $\begin{array}{l}\text { Effect of } \\
\text { antidepres- } \\
\text { sants, SSRIs vs. } \\
\text { SNRIs, on IL-6 } \\
\text { and TNFa }\end{array}$ & $\begin{array}{l}\text { Participant details: } \\
51 \text { MDD patients, } 30 \text { age- and } \\
\text { sex- matched controls. } \\
\text { Age: } P t(40 \pm 9) \\
\text { Sex: } \operatorname{Pt~}(28 \mathrm{~F}, 23 \mathrm{M})\end{array}$ & $\begin{array}{l}\text { Diagnosis - } \\
\text { DSM IV } \\
\text { HRSD for sever- } \\
\text { ity of depression } \\
\text { Baseline HRSD }\end{array}$ & $\begin{array}{l}\text { Medications - } \\
\text { Paroxetine } \\
\mathrm{n}=16, \text { ser- } \\
\text { traline } \mathrm{n}=15, \\
\text { fluvoxam- } \\
\text { ine } \mathrm{n}=10, \\
\text { milnacipran } \\
\mathrm{n}=10 \\
\text { Dosages } \\
\text { varied, titrated } \\
\text { to response }\end{array}$ & $\begin{array}{l}\text { Plasma } \\
\text { samples } \\
\text { collected } \\
\text { between } \\
0800- \\
1000 . \\
\text { IL-6, } \\
\text { TNF-a }\end{array}$ & $\begin{array}{l}\text { Clinical } \\
\text { Response defined as HRSD im- } \\
\text { provement < } 50 \% \text { of baseline } \\
\text { Immune } \\
\text { Plasma IL-6 level, but not plasma } \\
\text { TNF- } \alpha \text { level, was higher in SSRI- } \\
\text { refractory than SSRI-responsive } \\
\text { depressed patients, and higher } \\
\text { in SNRI-refractory than SNRI- } \\
\text { responsive depressed patients. } \\
\text { On the other hand, the plasma } \\
\text { BDNF level was significantly } \\
\text { lower in depressed patients than } \\
\text { in healthy controls, whereas } \\
\text { no difference was found in } \\
\text { plasma BDNF levels between } \\
\text { SSRI-responsive and -refractory } \\
\text { depressed patients or between } \\
\text { SNRI-responsive and -refractory } \\
\text { depressed patients. }\end{array}$ \\
\hline $\begin{array}{l}\text { Kraus et al. } \\
2002 \text { [73] }\end{array}$ & $\begin{array}{l}\text { Effect of } \\
\text { antidepres- } \\
\text { sants (ven- } \\
\text { lafaxine and } \\
\text { mirtazapine) } \\
\text { on biological } \\
\text { parameters } \\
\text { (BMI, weight, } \\
\text { leptin, TNF- } \alpha \text {, } \\
\text { TNF receptors) }\end{array}$ & $\begin{array}{l}\text { Study type: open-label over } \\
4 \text { weeks } \\
\text { Age: Mirtazapine group } \\
48.3 \pm 18.5 \text {; venlafaxine group } \\
45.7 \pm 15 \text {. }\end{array}$ & $\begin{array}{l}\text { Diagnosis: } \\
\text { MDD DSM-IV, } \\
\text { inpatient }\end{array}$ & $\begin{array}{l}\text { Medications: } \\
\text { Mirtazapine } \\
11 \\
\text { Venlafaxine } 9\end{array}$ & $\begin{array}{l}\text { Plasma } \\
\text { samples } \\
\text { of leptin, } \\
\text { TNF- } \alpha \text {, } \\
\text { TNFRp55, } \\
\text { TNFRp75. }\end{array}$ & $\begin{array}{l}\text { Mirtazapine: } \uparrow \text { weight (mean } \\
\text { gain: } 2.4 \mathrm{~kg} \text { ); } \uparrow \text { TNF- } \alpha \text { and TNF } \\
\text { receptors; } \uparrow \text { leptin. } \\
\text { Venlafaxine: } \downarrow \text { weight (mean } \\
\text { loss: } 0.4 \mathrm{~kg} \text { ); no change in leptin, } \\
\text { TNF-alpha, or TNF receptors. }\end{array}$ \\
\hline
\end{tabular}

escitalopram and nortriptyline, however this time they explored leukocyte gene expression profiles. IL-6 levels decreased significantly in responders $(p<0.0001)$, and this was present for both responders to escitalopram $(-12 \%, p=0.001)$ and to nortriptyline $(-6 \%, p=0.02)$. In non-responders there was no overall effect on $I L-6(+1 \%, p=0.5)$ but, when the 2 drugs were analysed separately, IL-6 did not change in the non-responders to escitalopram $(-2 \%, p=0.5)$ and increased in the non-responders to nortriptyline $(+7 \%, p=0.037)$. Antidepressant treatment (irrespective of type) significantly reduced the expression levels of $I L-1 \beta(-6 \%$, $p=0.006)$ and $\operatorname{MIF}(-24 \%, p<0.0001)$, and increased GR mRNA levels $(+5 \%, p=0.009)$ and $p 11$ levels $(+8 \%, p=0.005)$. Therefore, except for IL-6, all examined genes were modulated in the same way by both drugs. This may be due to the 2 drugs operating through the same serotonergic and noradrenergic pathways.

There are 2 studies which compare SSRIs with SNRIs. A direct comparison of immune effects of SSRIs (various types) and SNRIs was conducted in a study by Yoshimura et al. [67]. This study utilised 51 adult MDD patients and 30 age- and sexmatched controls. In this study, plasma IL-6 level, but not plasma TNF- $\alpha$ level, was higher in SSRI-refractory than SSRI-responsive depressed patients, and higher in SNRI-refractory than SNRIresponsive depressed patients. These findings suggest that patients with higher plasma IL-6 levels, but not higher TNF- $\alpha$ levels, might develop SSRI- or SNRI-resistant depression. In another study, Chang et al. [66] explored the effects of venlafax- ine (SNRI; $75 \mathrm{mg} /$ day) and fluoxetine (SSRI; $80 \mathrm{mg} /$ day) on CRP levels in MDD patients across a 6-week study. Patients with a higher CRP at baseline had a poorer treatment response, and both medications reduced CRP levels over 6 weeks. This suggests both antidepressant classes reduced CRP levels to similar magnitudes.

Comparative studies exploring adaptive immune factors Only a single study comparing the effects of antidepressant classes on cellular immune factors was identified ( Table 2 ). The study by Basterzi et al. [68] explored the effect of venlafaxine and fluoxetine on lymphocyte subsets (CD3, CD4, CD8, CD16/56, CD19, CD45, anti-HLA-DR) in MDD patients over 6 weeks. 69 MDD patients and 36 healthy controls were involved in this study. The dose ranges were $75-150 \mathrm{mg} /$ day and 20-40 mg/day, respectively. At baseline, patients with MDD had a significantly lower CD16/56 ratio and higher CD45 ratio (meaning CD45 numbers relative to all other CD lymphocyte numbers) compared to controls. CD45 is a protein tyrosine phosphatase best known as a leukocyte antigen. Biological functions of CD45 relevant to depression include: lymphocyte activation, cytokine production, and reduced serotonergic functioning through the mitogen activated protein kinase (MAPK) activation [69]. MAPK activation by cytokines may lead to low serotonin production given it can redirect the tryptophan metabolism to form neurotoxic kynurenine instead of serotonin [10]. Although 
Table 2 Clinical studies comparing the adaptive immune effects of antidepressants.

\begin{tabular}{|c|c|c|c|c|c|c|c|}
\hline Ref. & Objective & $\begin{array}{l}\text { Study type/details } \\
\text { Participant details }\end{array}$ & $\begin{array}{l}\text { Depression } \\
\text { details }\end{array}$ & Antidepressant info & Immune markers & Results & $\begin{array}{l}\text { Metho- } \\
\text { dological } \\
\text { weaknesses }\end{array}$ \\
\hline $\begin{array}{l}\text { Basterzi } \\
\text { et al. } \\
2010 \text { [64] }\end{array}$ & $\begin{array}{l}\text { Effect of } \\
\text { venlafaxine } \\
\text { vs. fluox- } \\
\text { etine on } \\
\text { lymphocyte } \\
\text { subsets in } \\
\text { depressive } \\
\text { patients }\end{array}$ & $\begin{array}{l}69 \text { MDD patients } \\
\text { and } 36 \text { healthy } \\
\text { controls. } \\
\text { Age: Pt vs. C } \\
\text { ( } 31 \pm 12 \text { vs. } 29 \pm 4) \\
\text { Sex: Pt vs. C ( } 49 F \text {, } \\
20 \text { M vs. } 19 F, 17 M)\end{array}$ & $\begin{array}{l}\text { DIAGNOSIS } \\
\text { - DSM IV } \\
\text { Severity } \\
\text { assessed by } \\
21-\text { HRDS } \\
\text { Mean HRDS } \\
27.7 \pm 4.5\end{array}$ & $\begin{array}{l}\text { Medications - ran- } \\
\text { domly assigned to } \\
\text { take fluoxetine } \mathrm{n}=33 \\
\text { or venlafaxine } \mathrm{n}=36 \\
\text { Fluoxetine } 20 \mathrm{mg} \\
\text { daily. } 40 \mathrm{mg} \text { if re- } \\
\text { sponse insufficient } \\
\text { Venlafaxine } 75 \mathrm{mg} \\
\text { daily. } 150 \mathrm{mg} \text { if not } \\
\text { responding }\end{array}$ & $\begin{array}{l}\text { Serum lymphocyte } \\
\text { subsets (CD3, CD4, } \\
\text { CD8, CD16/56, } \\
\text { CD19, CD45, } \\
\text { anti-HLA-DR) } \\
\text { Measured using } \\
\text { flow cytometry } \\
\text { at baseline and } 6 \\
\text { wks after start of } \\
\text { treatment }\end{array}$ & $\begin{array}{l}\text { Immune } \\
\text { CD45 values de- } \\
\text { creased significant- } \\
\text { ly in the VEN group } \\
\text { at the end of the } \\
\text { 6-week treatment } \\
\text { period whereas } \\
\text { no difference was } \\
\text { observed in the } \\
\text { FLX group. }\end{array}$ & $\begin{array}{l}27 \text { patients } \\
\text { completed } \\
\text { the study } \\
\text { from an } \\
\text { initial pool } \\
\text { of } 69\end{array}$ \\
\hline
\end{tabular}

MDD, major depressive disorder; HAM-D/HDRS, Hamilton Depression Rating Scale; DSM, Diagnostic and Statistical Manual of Mental Disorders; FLX, fluoxetine; VEN, venlafaxine

numerically higher in the venlafaxine-treated patients, treatment response rates between the fluoxetine $(53 \%)$ and the venlafaxine (75\%) groups were not statistically different. CD45 values were decreased significantly in the venlafaxine group at the end of the 6-week treatment period whereas no difference was observed in the fluoxetine group. By the $6^{\text {th }}$ study week, treatment responders showed a significantly higher CD16/56 ratio than non-responders. Interestingly, consistent changes in the absolute number of circulating B or T cells or in the helper/ inducer (CD4) or suppressor/cytotoxic (CD8) subsets were not observed. See 0 Fig. 3 for a graphical representation of the abovementioned comparative immune-modulatory effects of antidepressant classes.

\section{Discussion}

$\nabla$

A careful analysis of the immune-modulatory effects of antidepressant classes is critical for the development of novel treatment approaches. This is important given there are currently relatively high rates of treatment resistance; and innate and adaptive immune factors are involved in depression pathophysiology.

This literature review has noted some common findings on the effects of antidepressants on innate immune factors. Antidepressants do appear, in general, to reduce pro-inflammatory cytokine levels, particularly TNF- $\alpha$, IL- $1 \beta$ and IL-6. The previous meta-analysis by Hannestad et al. [21] suggests SSRIs exert the greatest anti-inflammatory effects. We caution conclusions regarding which antidepressant possesses the greater antiinflammatory effect. In adult depressed populations, pre-treatment levels of CRP informed later efficacy of escitalopram and nortriptyline - high CRP levels at baseline were associated with greater antidepressant effect of nortriptyline than escitalopram over time [22]. This potentially suggests nortriptyline is more anti-inflammatory than escitalopram. We defer to pre-clinical studies to further inform this debate. For example, an illuminating study by Tynan et al. [70] compared the anti-inflammatory effects of SSRIs and SNRIs on LPS-stimulated microglia in vivo. This study found SSRIs potently inhibited microglial TNF- $\alpha$ and nitric oxide (NO) production much greater than SNRIs. They found cAMP signalling was involved in regulating these antiinflammatory responses. Interestingly, the anti-inflammatory effects of these drugs differed depending on their concentra-

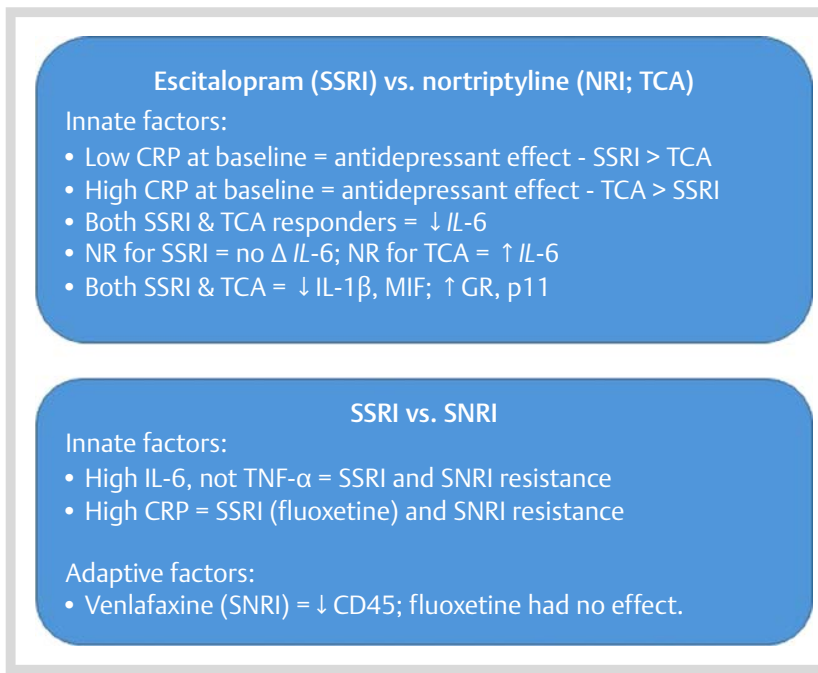

Fig. 3 Direct comparison of innate and adaptive immune effects of antidepressant classes. TNF, tumour necrosis factor; IL, interleukin; NK, natural killer; Th, T helper; ER, early responder; ENR, early non-responder; MCP, monocyte chemoattractant protein; SSRI, selective serotonin reuptake inhibitor; SNRI, serotonin noradrenaline reuptake inhibitor; TCA, tricyclic antidepressant; CRP, C-reactive protein. (Color figure available online only).

tions. A limited number of studies explore the effect of antidepressants on chemokines, hence making this area important for further investigation.

The effects of antidepressant classes on adaptive immune factors are complex and incompletely understood. This complexity likely stems from the incomplete understanding of the role of these immune factors in depression pathophysiology. We are aware of one human study directly comparing the effects of antidepressants on adaptive immune factors. In depressed adult subjects, CD45 values decreased with venlafaxine, however, there was no difference with fluoxetine [68]. We are not aware of other pre-clinical studies which compare the effects of antidepressants on the adaptive immune system.

To determine the immune-modulatory effects of antidepressant classes, we feel it is only suitable to explore this question with comparative, head-to-head studies. Non-comparative studies show too much methodological heterogeneity to justify meaningful conclusions. Heterogeneity stems from variations in 
length of treatment, cohort characteristics (including medical comorbidities), dosage used and immune factors analysed. The duration of studies ranges between cross-sectional studies and up to 52 weeks. The dosage of antidepressant medications differs, which may cause varying immune-modulatory effects - for example venlafaxine is predominantly an SSRI at low dose and an SNRI at high dose. The age range of the cohorts within these studies ranges from young adulthood through to old age. A recent meta-analysis of antidepressant clinical trials found antidepressants to be less efficacious in subjects 65 years and older compared with adult populations [71]. Depression pathophysiology and hence response to antidepressant treatment may differ in late-life depression due to the higher burden of vascular-related pathology (e.g., white matter hyperintensities) [72]. The level of pro-inflammatory general medical condition co-morbidity may also affect the comparative assessment between the anti-depressant classes; this differed between the abovementioned studies. A higher burden of general medical conditions is associated with lower antidepressant treatment efficacy [73]. Presence of heart disease, obesity or diabetes likely create a pro-inflammatory state $[74,75]$, hence possibly minimizing the treatment response of antidepressants. The variation in immune analyses and a wide array of cytokine, genetic and cellular immune markers assessed also makes firm conclusions regarding the effects of antidepressant classes difficult. Finally, there is substantial heterogeneity and inconsistent description of pre-treatments utilised prior to studies, as well as concomitant medications (e.g., benzodiazepines and mood stabilisers). We explored this in each study mentioned within the paper and found significant variability in washout period use and duration, concomitant anxiolytic and mood stabiliser use. These factors may further contribute to the possibility of artefacts given their potential effects on the immune system (for review see [76,77]). We have a number of recommendations to further develop this field. We recommend the development of clinical trials with comparative, head-to-head analyses between antidepressant classes. These trials should be conducted in discrete age populations to ensure homogeneity among trial participants. With these trials, it is recommended that immune analyses are conducted at baseline and at the end of the trial. This will assist in determining if baseline levels of immune factors can predict treatment response; and if treatment response is associated with other immune modulation. These immune analyses may include peripheral cytokine and chemokine levels, leukocyte gene expression, cellular/adaptive immune markers and immune-genetic testing. To date we are aware of only 1 study exploring the effects of antidepressants on cerebrospinal fluid (CSF) levels of cytokines. In a study by Martinez et al. [78], high baseline CSF TNF- $\alpha$ was found to predict poor treatment response to venlafaxine in a small RCT of subjects with MDD. Understanding the effects of antidepressants on CSF immune biomarkers is key given the close connection of CSF to the CNS milieu (Kern, 2014 \#127). We recommend the exploration of novel antidepressant compounds. Agomelatine, a serotonin and melatonin active compound, is yet to be assessed for immune effects in a clinical trial. A recent rodent study by Molteni et al. [79] did find a robust anti-inflammatory effect of this compound, and therefore shows promise for human trials. Clinical trials in this field must also explore for unique immune effects of varying dosages of antidepressants. Finally, pre-clinical tests are helpful in better understanding this field. Rodent studies, for example, allow a thorough and higher-throughput of assess- ments of antidepressants. Rodent studies also allow for the assessment of the brain tissue concentrations of antidepressants - as seen in the Tynan et al. study [70]. Finally, the interplay between neurotransmitters and both innate and adaptive parts of the immune system needs to be careful explored. At present, conclusions are difficult given there is a lack of research in the specific depression-like state, and there are few studies in general. Future studies must allow methods for isolation of components of the immune system in various neuroanatomical regions (i.e., immune cell subsets using flow cytometry, surface and intracellular actions and the use of transgenic rodents to pinpoint actions) [80].

\section{Conclusion}

$\nabla$

Exploring unique immune-modulatory effects of antidepressant classes is critical to further developing treatment approaches for depression. Currently there is substantial methodological heterogeneity in this field; hence larger, comparative studies with a more sophisticated structured assessment of immune factors from both the innate and adaptive immune system to better understand this field are required in the clinical field.

\section{Conflict of Interest}

$\nabla$

The authors declare no conflict of interest.

\section{References}

1 Murray CJ, Vos T, Lozano R et al. Disability-adjusted life years (DALYs) for 291 diseases and injuries in 21 regions, 1990-2010: a systematic analysis for the Global Burden of Disease Study 2010. Lancet 2012; 380: 2197-2223

2 Holtzheimer PE, Meeks TW, Kelley ME et al. A double blind, placebocontrolled pilot study of galantamine augmentation of antidepressant treatment in older adults with major depression. Int J Geriatr Psych 2008; 23: 625-631

3 Licinio J. Translational Psychiatry: leading the transition from the cesspool of devastation to a place where the grass is really greener. Transl Psychiatry 2011; 1 : e1

4 Rush AJ, Trivedi MH, Wisniewski SR et al. Bupropion-SR, sertraline, or venlafaxine-XR after failure of SSRIs for depression. N Engl J Med 2006; 354: 1231-1242

5 Rush AJ, Trivedi MH, Wisniewski SR et al. Acute and longer-term outcomes in depressed outpatients requiring one or several treatment steps: a STAR* D report. Am J Psychiatry 2006; 163: 1905-1917

6 Rush AJ, Trivedi MH, Wisniewski SR et al. Bupropion-SR, sertraline, or venlafaxine-XR after failure of SSRIs for depression. N Engl J Med 2006; 354: 1231-1242

7 Muller N, Hofschuster E, Ackenheil M et al. Investigations of the cellular immunity during depression and the free interval: evidence for an immune activation in affective psychosis. Prog Neuropsychopharmacol Biol Psychiatry 1993; 17: 713-730

8 Dowlati $Y$, Herrmann $N$, Swardfager $W$ et al. A meta-analysis of cytokines in major depression. Biol Psychiatry 2010; 67: 446-457

9 Haapakoski R, Mathieu J, Ebmeier KP et al. Cumulative meta-analysis of interleukins 6 and 1beta, tumour necrosis factor alpha and C-reactive protein in patients with major depressive disorder. Brain Behav Immun 2015; 49: 206-215

10 Dantzer R, O'Connor JC, Freund GG et al. From inflammation to sickness and depression: when the immune system subjugates the brain. Nat Rev Neurosci 2008; 9: 46-56

11 Miller AH, Maletic V, Raison CL. Inflammation and its discontents: the role of cytokines in the pathophysiology of major depression. Biol Psychiatry 2009; 65: 732-741

12 McAfoose J, Baune BT. Evidence for a cytokine model of cognitive function. Neurosci Biobehav Rev 2009; 33: 355-366

13 Eyre H, Baune BT. Neuroplastic changes in depression: a role for the immune system. Psychoneuroendocrinology 2012; 37: 1397-1416 
14 Haroon E, Raison CL, Miller AH. Psychoneuroimmunology meets neuropsychopharmacology: translational implications of the impact of inflammation on behavior. Neuropsychopharmacology 2012; 37: 137-162

15 Eyre H, Baune BT. Neuroplastic changes in depression: A role for the immune system. Psychoneuroendocrinology 2012; doi:10.1016/j. psyneuen.2012.03.019

16 Moylan S, Maes M, Wray NR et al. The neuroprogressive nature of major depressive disorder: pathways to disease evolution and resistance, and therapeutic implications. Mol Psychiatry 2012; doi:10.1038/ mp.2012.33

17 Leonard B, Maes $M$. Mechanistic explanations how cell-mediated immune activation, inflammation and oxidative and nitrosative stress pathways and their sequels and concomitants play a role in the pathophysiology of unipolar depression. Neurosci Biobehav Rev 2012; 36: 764-785

18 Setiawan E, Wilson AA, Mizrahi $R$ et al. Role of translocator protein density, a marker of neuroinflammation, in the brain during major depressive episodes. JAMA psychiatry 2015; 72: 268-275

19 Eyre HA, Stuart MJ, Baune BT. A phase-specific neuroimmune model of clinical depression. Prog Neuropsychopharmacol Biol Psychiatry 2014; 54: 265-274

20 Peng L, Verkhratsky A, Gu L et al. Targeting astrocytes in major depression. Expert Rev Neurother 2015; 15: 1299-1306

21 Hannestad J, Dellagioia N, Bloch M. The effect of antidepressant medication treatment on serum levels of inflammatory cytokines: a metaanalysis. Neuropsychopharmacology 2011; 36: 2452-2459

22 Uher R, Tansey KE, Dew $T$ et al. An inflammatory biomarker as a differential predictor of outcome of depression treatment with escitalopram and nortriptyline. Am J Psychiatry 2014; doi:10.1176/appi. ajp.2014.14010094

23 Martino M, Rocchi G, Escelsior A et al. Immunomodulation mechanism of antidepressants: interactions between serotonin/norepinephrine balance and Th1/Th2 bBalance. Curr Neuropharmacol 2012; 10 : 97-123

24 Ransohoff RM, Brown MA. Innate immunity in the central nervous system. J Clin Invest 2012; 122: 1164-1171

25 Martino G, Pluchino S, Bonfanti L et al. Brain regeneration in physiology and pathology: the immune signature driving therapeutic plasticity of neural stem cells. Physiol Rev 2011; 91: 1281-1304

26 Stuart MJ, Baune BT. Chemokines and chemokine receptors in mood disorders, schizophrenia, and cognitive impairment: a systematic review of biomarker studies. Neurosci Biobehav Rev 2014; 42: 93-115

27 Filiano AJ, Gadani SP, Kipnis J. Interactions of innate and adaptive immunity in brain development and function. Brain Res 2014; doi:10.1016/j.brainres.2014.07.050

28 Moher D, Altman DG, Liberati A et al. PRISMA statement. Epidemiology 2011; 22: 128 author reply 128

29 Janssen DG, Caniato RN, Verster JC et al. A psychoneuroimmunological review on cytokines involved in antidepressant treatment response. Hum Psychopharmacol 2010; 25: 201-215

30 Tsao CW, Lin YS, Chen CC et al. Cytokines and serotonin transporter in patients with major depression. Prog Neuropsychopharmacol Biol Psychiatry 2006; 30: 899-905

31 O'Brien SM, Scott LV, Dinan TG. Antidepressant therapy and C-reactive protein levels. Br J Psychiatry 2006; 188: 449-452

32 Leo R, Di Lorenzo G, Tesauro $M$ et al. Association between enhanced soluble CD40 ligand and proinflammatory and prothrombotic states in major depressive disorder: pilot observations on the effects of selective serotonin reuptake inhibitor therapy. J Clin Psychiatry 2006; 67: $1760-1766$

33 Basterzi AD, Aydemir C, Kisa C et al. IL-6 levels decrease with SSRI treatment in patients with major depression. Hum Psychopharmacol 2005; 20: 473-476

34 Tuglu C, Kara SH, Caliyurt $O$ et al. Increased serum tumor necrosis factor-alpha levels and treatment response in major depressive disorder. Psychopharmacology 2003; 170: 429-433

35 Sluzewska A, Rybakowski JK, Laciak $M$ et al. Interleukin-6 serum levels in depressed patients before and after treatment with fluoxetine. Ann N Y Acad Sci 1995; 762: 474-476

36 Hernandez ME, Mendieta D, Martinez-Fong $D$ et al. Variations in circulating cytokine levels during 52 week course of treatment with SSRI for major depressive disorder. Eur Neuropsychopharmacol 2008; 18: 917-924

37 Eller T, Vasar V, Shlik $J$ et al. Pro-inflammatory cytokines and treatment response to escitalopram in major depressive disorder. Prog Neuropsychopharmacol Biol Psychiatry 2008; 32: 445-450
38 Sutcigil L, Oktenli C, Musabak $U$ et al. Pro- and anti-inflammatory cytokine balance in major depression: effect of sertraline therapy. Clin Dev Immunol 2007 2007: 76396

39 Mamdani F, Berlim MT, Beaulieu MM et al. Gene expression biomarkers of response to citalopram treatment in major depressive disorder. Transl Psychiatry 2011; 1: e13

40 Mamdani F, Berlim MT, Beaulieu MM et al. Pharmacogenomic predictors of citalopram treatment outcome in major depressive disorder World J Biol Psychiatry 2014; 15: 135-144

41 Honda $K$, Yanai $H$, Negishi $H$ et al. IRF-7 is the master regulator of type-I interferon-dependent immune responses. Nature 2005; 434: 772-777

42 Paun A, Pitha PM.. The IRF family, revisited. Biochimie 2007; 89: 744-753

$43 \mathrm{Lu} R, \mathrm{Au} W C$, Yeow WS et al. Regulation of the promoter activity of interferon regulatory factor-7 gene. Activation by interferon and silencing by hypermethylation. J Biol Chem 2000; 275: 31805-31812

44 Wicks SJ, Grocott T, Haros $K$ et al. Reversible ubiquitination regulates the Smad/TGF-beta signalling pathway. Biochem Soc Trans 2006; 34: 761-763

45 Myint AM, Leonard BE, Steinbusch HW et al. Th1, Th2, and Th3 cytokine alterations in major depression. J Affect Disord 2005; 88: 167-173

46 Carlin AF, Uchiyama S, Chang YC et al. Molecular mimicry of host sialylated glycans allows a bacterial pathogen to engage neutrophil Siglec-9 and dampen the innate immune response. Blood 2009; 113: 3333-3336

47 Chen GY, Tang J, Zheng $P$ et al. CD24 and Siglec-10 selectively repress tissue damage-induced immune responses. Science 2009; 323: 1722 1725

48 Wang $Y$, Neumann H. Alleviation of neurotoxicity by microglial human Siglec-11. J Neurosci 2010; 30: 3482-3488

49 Frank MG, Hendricks SE, Johnson DR et al. Antidepressants augment natural killer cell activity: in vivo and in vitro. Neuropsychobiology 1999; 39: 18-24

50 Kook AI, Mizruchin A, Odnopozov N et al. Depression and immunity: the biochemical interrelationship between the central nervous system and the immune system. Biol Psychiatry 1995; 37: 817-819

51 Hernandez ME, Martinez-Fong D, Perez-Tapia $M$ et al. Evaluation of the effect of selective serotonin-reuptake inhibitors on lymphocyte subsets in patients with a major depressive disorder. Eur Neuropsychopharmacol 2010; 20: 88-95

52 Frank MG, Hendricks SE, Burke WJ et al. Clinical response augments NK cell activity independent of treatment modality: a randomized double-blind placebo controlled antidepressant trial. Psychol Med 2004; 34: 491-498

53 Gladkevich A, Kauffman HF, Korf J. Lymphocytes as a neural probe: potential for studying psychiatric disorders. Prog Neuropsychopharmacol Biol Psychiatry 2004; 28: 559-576

54 Ravindran AV, Griffiths J, Merali Z et al. Lymphocyte subsets associated with major depression and dysthymia: modification by antidepressant treatment. Psychosom Med 1995; 57: 555-563

55 Rothermundt $M$, Arolt $V$, Fenker J et al. Different immune patterns in melancholic and non-melancholic major depression. Eur Arch Psychiatry Clin Neurosci 2001; 251: 90-97

56 Iken K, Chheng S, Fargin A et al. Serotonin upregulates mitogen-stimulated B lymphocyte proliferation through 5-HT1A receptors. Cell Immunol 1995; 163: 1-9

57 Piletz JE, Halaris A, Iqbal $O$ et al. Pro-inflammatory biomakers in depression: treatment with venlafaxine. World J Biol Psychiatry 2009; 10: 313-323

$58 \mathrm{Li}$ Z, Qi D, Chen J et al. Venlafaxine inhibits the upregulation of plasma tumor necrosis factor-alpha (TNF-alpha) in the Chinese patients with major depressive disorder: a prospective longitudinal study. Psychoneuroendocrinology 2013; 38: 107-114

59 Fornaro M, Rocchi G, Escelsior A et al. Might different cytokine trends in depressed patients receiving duloxetine indicate differential biological backgrounds. J Affect Disord 2013; 145: 300-307

60 Kalman J, Palotas A, Juhasz A et al. Impact of venlafaxine on gene expression profile in lymphocytes of the elderly with major depression - evolution of antidepressants and the role of the "neuroimmune" system. Neurochem Res 2005; 30: 1429-1438

61 Lanquillon S, Krieg JC, Bening-Abu-Shach $U$ et al. Cytokine production and treatment response in major depressive disorder. Neuropsychopharmacology 2000; 22: 370-379

62 Weizman R, Laor N, Podliszewski E et al. Cytokine production in major depressed patients before and after clomipramine treatment. Biol Psychiatry 1994; 35: 42-47

63 Schleifer SJ, Keller SE, Bartlett JA. Depression and immunity: clinical factors and therapeutic course. Psychiatry Res 1999; 85: 63-69 
64 Narita K, Murata T, Takahashi T et al. Plasma levels of adiponectin and tumor necrosis factor-alpha in patients with remitted major depression receiving long-term maintenance antidepressant therapy. Prog Neuropsychopharmacol Biol Psychiatry 2006; 30: 1159-1162

65 Cattaneo A, Gennarelli M, Uher R et al. Candidate genes expression profile associated with antidepressants response in the GENDEP study: differentiating between baseline 'predictors' and longitudinal 'targets'. Neuropsychopharmacology 2013; 38: 377-385

66 Chang HH, Lee IH, Gean PW et al. Treatment response and cognitive impairment in major depression: association with C-reactive protein. Brain Behav Immun 2012; 26: 90-95

67 Yoshimura R, Hori H, Ikenouchi-Sugita A et al. Higher plasma interleukin-6 (IL-6) level is associated with SSRI- or SNRI-refractory depression. Prog Neuropsychopharmacol Biol Psychiatry 2009; 33: 722-726

68 Basterzi AD, Yazici K, Buturak V et al. Effects of venlafaxine and fluoxetine on lymphocyte subsets in patients with major depressive disorder: a flow cytometric analysis. Prog Neuropsychopharmacol Biol Psychiatry 2010; 34: 70-75

69 Maxeiner HG, Rojewski MT, Schmitt A et al. Flow cytometric analysis of $\mathrm{T}$ cell subsets in paired samples of cerebrospinal fluid and peripheral blood from patients with neurological and psychiatric disorders. Brain Behav Immun 2009; 23: 134-142

70 Tynan RJ, Weidenhofer J, Hinwood M et al. A comparative examination of the anti-inflammatory effects of SSRI and SNRI antidepressants on LPS stimulated microglia. Brain Behav Immun 2012; 26: 469-479

71 Tedeschini E, Levkovitz Y, Iovieno $N$ et al. Efficacy of antidepressants for late-life depression: a meta-analysis and meta-regression of placebocontrolled randomized trials. J Clin Psychiatry 2011; 72: 1660-1668
72 Taylor WD, Aizenstein HJ, Alexopoulos GS. The vascular depression hypothesis: mechanisms linking vascular disease with depression. Mol Psychiatry 2013; 18: 963-974

73 Otte C. Incomplete remission in depression: role of psychiatric and somatic comorbidity. Dialogues Clin Neurosci 2008; 10: 453-460

74 Baune BT, Stuart M, Gilmour A et al. The relationship between subtypes of depression and cardiovascular disease: a systematic review of biological models. Transl Psychiatry 2012; 2: e92

75 Stuart MJ, Baune BT. Depression and type 2 diabetes: inflammatory mechanisms of a psychoneuroendocrine co-morbidity. Neurosci Biobehav Rev 2012; 36: 658-676

76 Himmerich $H$, Bartsch S, Hamer $H$ et al. Impact of mood stabilizers and antiepileptic drugs on cytokine production in-vitro. J Psychiatr Res 2013; 47: 1751-1759

77 Ramirez K, Niraula A, Sheridan JF. GABAergic modulation with classical benzodiazepines prevent stress-induced neuro-immune dysregulation and behavioral alterations. Brain Behav Immun 2016; 51: 154-168

78 Martinez JM, Garakani A, Yehuda R et al. Proinflammatory and "resiliency" proteins in the CSF of patients with major depression. Depress Anxiety 2012; 29: 32-38

79 Molteni R, Macchi F, Zecchillo C et al. Modulation of the inflammatory response in rats chronically treated with the antidepressant agomelatine. Eur Neuropsychopharmacol 2013; 23: 1645-1655

80 Baganz NL, Blakely RD. A dialogue between the immune system and brain, spoken in the language of serotonin. ACS Chem Neurosci 2013; 4: $48-63$ 